\title{
SOME NEW INEQUALITIES FOR MEANS IN TWO VARIABLES
}

\author{
LING ZHU
}

Abstract. In this paper, some new bounds for $L^{p}(x, y)$ and $I^{p}(x, y)$ in terms of $A^{p}(x, y)$ and $G^{p}(x, y)$ are established.

Mathematics subject classification (2000): 26E60, 26D07. constants.

Key words and phrases: Geometric mean, logarithmic mean, identric mean, arithmetic mean, best

\section{REFERENCES}

[1] D. S. Mitrinovic, Analytic inequalities, Springer-Verlag, 1970.

[2] B. Ostle And H. L. Terwilliger, A comparison of two means, Proc. Montana Acad. Sci. 17 (1957), 67-70.

[3] E. B. Leach and M. C. Sholander., Extended mean values, J. Math. Anal. Appl. 92 (1983), 207-223.

[4] J. SANDOR, On the identric and logarithmic means, Aequat. Math. 40 (1990), 261-270.

[5] B. C. CARLSON,, The logarithmic mean, Amer. Math. Monthly 79 (1972), 615-618.

6] H. AlzeR AND S.-L. QIU, Inequalities for means in two variables, Arch. Math. 80 (2003), 201-215.

[7] L. ZHU AND J. H. WU, The weighted arithmetic and geometric means of the arithmetic mean and the geometric Mean, Journal of Mathematics for Technology (in Chinese) 14 (1998), 150-154.

[8] L. ZHU, From chains for mean value Inequalities to Mitrinovic's problem II, Int. J. Educ. Sci. Technol. 36 (2005), 118-125.

[9] J. SANDOR, A note on some Inequalities for means, Arch. Math. 56 (1991), 471-473.

[10] J. SANDOR AND T. TRIF, Some new inequalities for means of two arguments, Internat. J. Math. Math. Sci. 25 (2001), 525-532.

[11] T. TRIF, Note on certain inequalities for means in two variables, J. Inequal. Pure Appl. Math. 6 (2005), article 43, 5 pp. (electronnic).

[12] G. D. ANDERSON, S.-L. QIU, M. K. VAMANAMURThy, AND M. Vuorinen, Generalized elliptic integral and modular equations, Pacific J. Math. 192 (2000), 1-37.

[13] I. PINELIS, L'Hospital type results for monotonicity, with applications, J. Inequal. Pure Appl. Math. 3 (2002), article 5, 5 pp. (electronnic).

[14] Zs. PALES, Inequalities for differences of powers, J. Math. Anal. Appl. 131 (1988), 271-281.

[15] P. S. BuLleN, Handbook of means and their inequalities, Kluwer Academic Publishers, 2003. 